\title{
Article \\ Discovery of Novel Backusella (Backusellaceae, Mucorales) Isolated from Invertebrates and Toads in Cheongyang, Korea
}

\author{
Thuong T.T. Nguyen ${ }^{1}$, Kerstin Voigt ${ }^{2}$ D, André Luiz Cabral Monteiro de Azevedo Santiago ${ }^{3}$, Paul M. Kirk ${ }^{4}$ \\ and Hyang Burm Lee ${ }^{1, *(\mathbb{D})}$
}

\section{check for} updates

Citation: Nguyen, T.T.T.; Voigt, K.; Santiago, A.L.C.M.d.A.; Kirk, P.M.; Lee, H.B. Discovery of Novel Backusella (Backusellaceae, Mucorales) Isolated from Invertebrates and Toads in Cheongyang, Korea. J. Fungi 2021, 7, 513. https://doi.org/10.3390/ jof7070513

Academic Editors: Samantha

C. Karunarathna and

Saowaluck Tibpromma

Received: 6 June 2021

Accepted: 23 June 2021

Published: 27 June 2021

Publisher's Note: MDPI stays neutral with regard to jurisdictional claims in published maps and institutional affiliations.

Copyright: (c) 2021 by the authors. Licensee MDPI, Basel, Switzerland. This article is an open access article distributed under the terms and conditions of the Creative Commons Attribution (CC BY) license (https:/ / creativecommons.org/licenses/by/ $4.0 /)$.
1 Environmental Microbiology Laboratory, Department of Agricultural Biological Chemistry, College of Agriculture \& Life Sciences, Chonnam National University, Gwangju 61186, Korea; ngthuongthuong@gmail.com

2 JMRC at Leibniz Institute for Natural Product Research and Infection Biology e.V. HKI and Friedrich Schiller University Jena, 07745 Jena, Germany; Kerstin.Voigt@hki-jena.de

3 Departamento de Micologia, Federal University of Pernambuco, Av. da Engenharia, s/n, Recife PE 50740-600, Brazil; andrelcabral@msn.com

4 Biodiversity Informatics and Spatial Analysis, Jodrell Laboratory, Royal Botanic Gardens Kew, Surrey TW9 3DS, UK; P.Kirk@kew.org

* Correspondence: hblee@jnu.ac.kr; Tel.: +82-(0)62-530-2136

Abstract: Three novel fungal species, Backusella chlamydospora sp. nov., B. koreana sp. nov., and B. thermophila sp. nov., as well as two new records, B. oblongielliptica and B. oblongispora, were found in Cheongyang, Korea, during an investigation of fungal species from invertebrates and toads. All species are described here using morphological characters and sequence data from internal transcribed spacer sequences of ribosomal DNA and large subunit of the ribosomal DNA. Backusella chlamydospora is different from other Backusella species by producing chlamydospores. Backusella koreana can be distinguished from other Backusella species by producing abundant yeast-like cells. Backusella thermophila is characterized by a variable (subglobose to oblong, applanate to oval, conical and ellipsoidal to pyriform) columellae and grows well at $37^{\circ} \mathrm{C}$. Multigene phylogenetic analyses of the combined ITS and LSU rDNA sequences data generated from maximum likelihood and MrBayes analyses indicate that B. chlamydospora, B. koreana, and B. thermophila form distinct lineages in the family Backusellaceae. Detailed descriptions, illustrations, phylogenetic tree, and taxonomic key to the Backusella species present in Korea are provided.

Keywords: 3 new taxa; ITS; LSU; Mucoromycota; phylogeny; taxonomy

\section{Introduction}

The genus Backusella (Mucoromycota, Mucorales) was established by Ellis and Hesseltine in 1969 [1] to describe Mucor-like species producing persistent-walled sporangiola on the lateral branches of their sporangiophores, which terminate in single deliquescentwalled sporangia; Backusella circina J.J. Ellis \& Hesselt. is the type strain for this genus. Two years later, Pidoplichko and Milko [2] transferred Thamnidium ctenidium Durrell \& M. Fleming to Backusella as B. ctenidia (Durrell \& M. Fleming) Pidopl. \& Milko and assigned both B. circina and B. ctenidia to the family Thamnidiaceae Fitzp. Benny and Benjamin [3] monographed the genus Backusella, leading to the definition of a new species, B. lamprospora (Lendn.) Benny \& R.K. Benjamin (syn.: Mucor lamprosporus Lendn.). Between 1975 and 2013 the genus Backusella included only three species: B. circina, B. lamprospora, and B. ctenidia. However, Walther et al. [4] revised the Mucorales based on their ITS rDNA and LSU rDNA data and transferred all Mucor species with transitorily recurved sporangiophores to Backusella, while B. ctenidia was transferred to Mucor. This study expands the knowledge of genus Backusella to include nine species. Over the last few years, four new Backusella species were described based on phylogenetic and morphological analyses. The corresponding 
type strains were isolated in Brazil and Korea and named as follows: B. azygospora T.R.L. Cordeiro, Hyang B. Lee \& A.L. Santiago [5], B. constricta D.X. Lima, C.A.F. de Souza \& A.L. Santiago [6], B. gigacellularis J.I. de Souza, Piris-Zottar. \& Harakava [7], and B. locustae Hyang B. Lee, S.H. Lee \& T.T.T. Nguyen [8]. Recently, 10 new Backusella species were discovered in Australia by Urquhart et al. [9]—namely, B. australiensis, B. liffmaniae, B. luteola, B. macrospora, B. mclennaniae, B. morwellensis, B. parvicylindrica, B. psychrophila, B. tarrabulga, and $B$. westeae. Consequently, 25 species of Backusella are currently recorded in the Index Fungorum (www.indexfungorum.org; accessed 16 May 2021).

Voigt and Kirk (2012) established a family Backusellaceae to accommodate Backusella, based on morphological characters of sporangiophores and producing sporangiola in addition to sporangia in some species [10].

Members of Backusella, the unique genus of Backusellaceae, have been retrieved from soil, leaf litter, dung, moist wall, agarics, decaying wood, Fragaria, diseased roots, and Medicago sativa [3-9,11-13]. However, none of the Backusella species were isolated from invertebrates and toads. Thus, discovering new fungal species in specific and poorly studied substrates is pivotal for deepening our understanding of the biodiversity and phylogeny of Backusella as well as the actual diversity of mucoralean fungi. In Korea, only two species of this genus, B. circina and B. locustae, have been described $[8,11]$. Thus, many Backusella species still need to be investigated in Korea.

The aim of this study was to improve our understanding of the occurrence and distribution of Backusella species from Korea and to describe three new species. This is also the first report of B. oblongielliptica and B. oblongispora in Korea. A key to the Backusella species present in Korea is provided.

\section{Materials and Methods}

\subsection{Sampling and Fungal Isolation}

Theuronema hilgendorfi hilgendorfi (Scutigeromorpha, Scutigeridae), Porcellio scaber (Isopoda, Porcellinidae), Timomenus komarovi (Dermaptera, Forficulidae), Gryllus bimaculatus (Orthoptera, Gryllidae), Scolopendra morsitans (Scolopendromorpha, Scolopendridae), and Bufo gargarizans (Anura, Bufonidae) were collected at Kunryang-ri $\left(36^{\circ} 44^{\prime} 00.2^{\prime \prime} \mathrm{N}\right.$ $126^{\circ} 78^{\prime} 18.0^{\prime \prime}$ E), Cheongyang, located in Chungnam Province, South Korea (Figure 1). The samples were captured and handled with gloved hands and were placed in polyethylene bags, Falcon conical tubes, and stored at ambient temperature until transported to the laboratory.

To isolate the fungal strains from Bufo gargarizans: the skin was swabbed with sterilized cotton swabs and then streaked on potato dextrose agar (PDA: Difco Laboratories, Detroit, MI, USA) with antibiotics (streptomycin sulfate $100 \mathrm{mg} / \mathrm{L}$ and penicillin $100 \mathrm{mg} / \mathrm{L}$ ). The plates were then placed in the dark at $25{ }^{\circ} \mathrm{C}$ for $3-7$ days. Bufo gargarizans were quickly released to the original site of collection after isolation of fungi.

To isolate the fungal strains from Theuronema hilgendorfi hilgendorfi, Porcellio scaber, Timomenus komarovi, Gryllus bimaculatus, and Scolopendra morsitans: samples were removed from the bags or Falcon tubes and transferred to clean Petri dishes. Bodies were then broken up into small pieces and placed on PDA. The plates were then placed in the dark at $25{ }^{\circ} \mathrm{C}$ and checked under a stereomicroscope every day after the second day of incubation. Then, hyphal tips were transferred to fresh PDA. Single-spore cultures were established as described by Choi et al. [14]. Briefly, spores from a single sporangium after $2-4$ days incubation were transferred to sterilized water using capillary tubes and then vortexed to obtain a homogeneous spore suspension. Spore suspensions were diluted several times (1:10) and $50 \mu \mathrm{L}$ of each dilution was spread on PDA medium. The plates were then incubated at $25{ }^{\circ} \mathrm{C}$ to allow for spore germination. Colonies from single spores were transferred to a new PDA plate and used for DNA extraction. Ex-type living cultures were deposited at Chonnam National University Fungal Collection, Gwangju, South Korea (CNUFC), Gwangju, Korea. Dried cultures were deposited in the Herbarium Chonnam National University, Gwangju, Korea. 


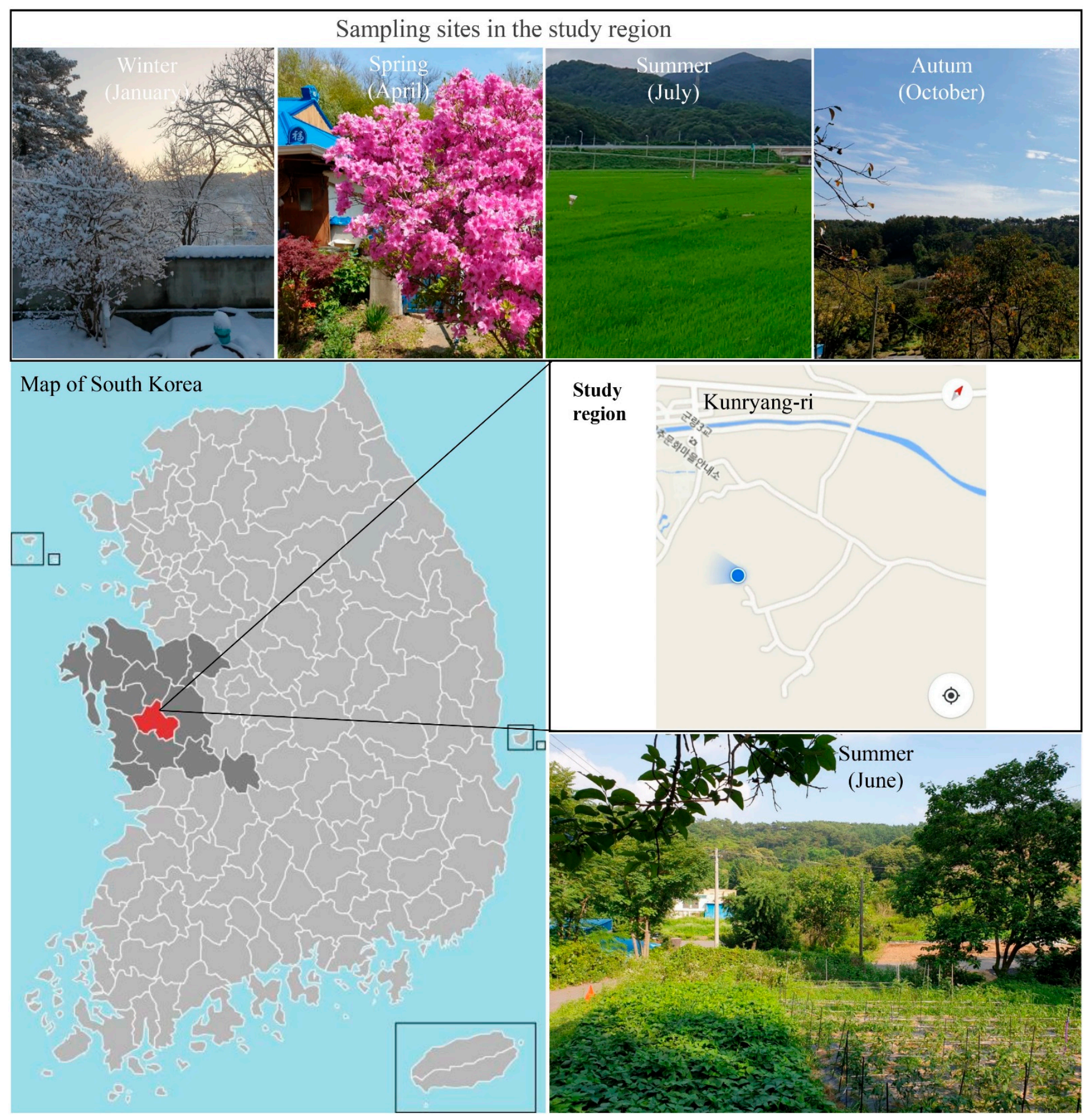

Figure 1. Map of sample collection sites. Samples were collected at Kunryang-ri, Cheongyang-eup, Cheongyang, Chungnam Province, Korea. Blue cursor represents the main area of Kunryang-ri for collection.

\subsection{Morphological Studies}

Pure cultures of Backusella spp. were grown on synthetic mucor agar (SMA: $40 \mathrm{~g}$ dextrose, $2 \mathrm{~g}$ asparagine, $0.5 \mathrm{~g} \mathrm{KH}_{2} \mathrm{PO}_{4}, 0.25 \mathrm{~g} \mathrm{MgSO}_{4} \cdot 7 \mathrm{H}_{2} \mathrm{O}, 0.5 \mathrm{mg}$ thiamine hydrochloride, and $15 \mathrm{~g}$ agar in $1 \mathrm{~L}$ of deionized water), PDA, and malt extract agar (MEA: $40 \mathrm{~g}$ malt extract, $4 \mathrm{~g}$ yeast extract, and $15 \mathrm{~g}$ agar in $1 \mathrm{~L}$ of deionized water). Plates were incubated at $25{ }^{\circ} \mathrm{C}$ in the dark for 5 to 14 days. Cultures grown on SMA at $25^{\circ} \mathrm{C}$ were photographed, and the dimensions of sporangia, sporangiola, columellae, sporangiospores, and chlamydospores were measured. Fragments of mycelia were removed from each culture and 
placed onto microscope slides with $60 \%$ lactic acid. A differential interference contrast microscope (Olympus BX51, Olympus, Tokyo, Japan) was used to generate digital images. For temperature studies, the isolates were grown in triplicates on SMA and were incubated at $10,20,25,30,37$, or $40^{\circ} \mathrm{C}$. Colony growth was measured every $24 \mathrm{~h}$ for 7 days.

\subsection{DNA Extraction, PCR, Cloning, and Sequencing}

Backusella spp. were cultured on cellophane over PDA at $25^{\circ} \mathrm{C}$ for 3 days. The mycelial mass was collected by scraping from the surface of cellophane and was placed in $1.5 \mathrm{~mL}$ sterile Eppendorf tubes. Genomic DNA was then extracted using the SolgTM Genomic DNA Preparation Kit (Solgent Co. Ltd., Daejeon, Korea) according to the manufacturer's protocol. The purified DNA was stored at $-20^{\circ} \mathrm{C}$ for later use. Two regions were amplified: the internal transcribed spacer (ITS) region, using the primers V9G/ITS $4[15,16]$ and ITS1/ITS4 [16]; and the large subunit (LSU) rRNA gene region, using the primers LROR [17] and LR7 [18]. These target regions, the ITS, and the LSU rRNA gene, were amplified by PCR in $20 \mu \mathrm{L}$ reaction mixtures containing $2 \mu \mathrm{L}$ of genomic DNA, $1.5 \mu \mathrm{L}$ of each primer $(5 \mathrm{pM}), 14 \mu \mathrm{L}$ of sterile water, and $1 \mu \mathrm{L}$ of PCR premix (Bioneer, Daejeon, Korea). Reaction mixtures were pre-heated at $95^{\circ} \mathrm{C}$ for $4 \mathrm{~min}$, and PCR was performed as follows: 30 cycles of $45 \mathrm{~s}$ at $95{ }^{\circ} \mathrm{C}, 30 \mathrm{~s}$ at $52{ }^{\circ} \mathrm{C}$, and $45 \mathrm{~s}$ at $72{ }^{\circ} \mathrm{C}$, with a final extension at $72{ }^{\circ} \mathrm{C}$ for $7 \mathrm{~min}$, followed by cooling at $4{ }^{\circ} \mathrm{C}$. PCR products were visualized in $1 \%(w / v)$ agarose gel electrophoresis. The PCR products were then purified using an Accuprep PCR Purification Kit (Bioneer) and sequenced on the ABI PRISM 3730XL Genetic Analyzer (Applied Biosystems, Foster City, CA, USA) using the same primers employed for PCR. In some cases, it is necessary to clone the ITS sequences before sequencing. PCR products were cloned using the pGEM-T Easy Vector System cloning kit (Promega, Madison, WI, USA), following the manufacturer's instructions. These clones were sequenced using the primers M13F forward (5'-GTAAAACGACGGCCAGT-3') and M13R-pUC reverse (5'-CAGGAAACAGCTATGAC-3').

\subsection{Sequence Alignment and Phylogenetic Analyses}

Each generated sequence was checked for the presence of ambiguous bases and was assembled using Lasergene SeqMan program from DNASTAR, Inc. (Madison, WI, USA). Edited sequences were blasted against the NCBI GenBank nucleotide database (https:/ /blast.ncbi.nlm.nih.gov/Blast.cgi; 8 September 2020) to search for closest relatives. Sequences of all the accepted Backusella species according to the last update of the Index Fungorum database were retrieved from GenBank. Sequences were aligned using MAFFT (http://mafft.cbrc.jp/alignment/server; 15 January 2021) with the algorithm L-INS-I. Aligned sequences were automatically trimmed using trimAl [19] with the gappyout method. Data were converted from a fasta format to nexus and phylip formats using the online tool Alignment Transformation Environment (https:/ / sing.ei.uvigo.es/ALTER/; 15 January 2021) [20]. Phylogenetic reconstructions by maximum likelihood (ML) and Bayesian inference (BI) were carried out using PhyML 3.0 [21] and MrBayes 3.2.2 [22], respectively. We performed the ML analysis using 1000 bootstrap replicates. BI analyses were performed using three million Markov chain Monte Carlo (MCMC) generations. The sample frequency was set to 100 , and the first $25 \%$ of trees were removed as burn-in. The best substitution models for each data partition were estimated using jModelTest v.2.1.10 according to the Akaike criterion $[23,24]$. The newly obtained sequences were deposited in the GenBank database under the accession numbers provided in Table 1. 
Table 1. Taxon, collection number, sequence, and GenBank accession number relative to all ITS and LSU sequences used in this study.

\begin{tabular}{|c|c|c|c|c|c|}
\hline \multirow[t]{2}{*}{ Taxon Name } & \multirow[t]{2}{*}{ Strain Number } & \multirow[t]{2}{*}{ Host/Substrate } & \multirow[t]{2}{*}{ Country } & \multicolumn{2}{|c|}{$\begin{array}{c}\text { GenBank Accession } \\
\text { Number }\end{array}$} \\
\hline & & & & ITS & LSU \\
\hline B. australiensis & UoMAU34 $^{\mathrm{T}}$ & Leaf litter & Australia & MK959062 & MK958800 \\
\hline B. australiensis & UoMAU33 & - & Australia & - & MK958801 \\
\hline B. azygospora & URM $8065^{\mathrm{T}}$ & Soil & Brazil & MK625216 & MK625222 \\
\hline B. chlamydospora & CNUFC PS1 $^{\mathrm{T}}$ & Porcellio scaber & South Korea & MZ171385 & MZ148709 \\
\hline B. chlamydospora & CNUFC HL7 & Theuronema hilgendorfi hilgendorfi & South Korea & MZ171386 & MZ148710 \\
\hline B. circina & CBS $128.70^{\mathrm{T}}$ & Soil with lichens & USA & JN206258 & JN206529 \\
\hline B. constricta & URM $7322^{\mathrm{T}}$ & Soil & Brazil & KT937158 & КT937156 \\
\hline B. dispersa & CBS 195.28 & Fallen leaf & USA & JN206271 & JN206530 \\
\hline B. dispersa & UoMAU119 & - & Australia & - & MK958770 \\
\hline B. dispersa & UoMAU116 & - & Australia & - & MK958769 \\
\hline B. gigacellularis & CCIBt $3866^{\mathrm{T}}$ & Leaf litter canopy-plates & Brazil & KF742415 & - \\
\hline B. grandis & CBS $186.87^{\mathrm{T}}$ & Dung of mouse & India & JN206252 & JN206527 \\
\hline B. indica & CBS $786.70^{\mathrm{LT}}$ & - & India & JN206255 & JN206526 \\
\hline B. koreana & CNUFC CM05 $^{\mathrm{T}}$ & Scolopendra morsitans & South Korea & MZ171387 & MZ148711 \\
\hline B. koreana & CNUFC CM06 & Scolopendra morsitans & South Korea & MZ171388 & MZ148712 \\
\hline B. lamprospora & CBS $118.08^{\mathrm{T}}$ & - & Switzerland & JN206268 & JN206531 \\
\hline B. liffmaniae & UoMAU58 ${ }^{\mathrm{T}}$ & Leaf litter & Australia & MK959065 & MK958734 \\
\hline B. liffmaniae & UoMAU128 & - & Australia & - & MK958735 \\
\hline B. locustae & EML-SFB4 & Grasshopper feces & South Korea & KY449293 & KY449290 \\
\hline B. locustae & EML-SFB2 $^{\mathrm{T}}$ & Grasshopper feces & South Korea & KY449291 & KY449292 \\
\hline B. luteola & UoMAU6 $^{\mathrm{T}}$ & Leaf litter & Australia & MK959058 & MK958795 \\
\hline B. luteola & UoMAU36 & - & Australia & - & MK958794 \\
\hline B. macrospora & UoMAU7 $^{\mathrm{T}}$ & Leaf litter & Australia & MK959107 & MK958628 \\
\hline B. mclennaniae & UoMAU11 $^{\mathrm{T}}$ & Leaf litter & Australia & MK958776 & MK958776 \\
\hline B. mclennaniae & UoMAU12 & - & Australia & MK959087 & MK958777 \\
\hline B. morwellensis & UoMAU16 $^{\mathrm{T}}$ & Leaf litter & Australia & MK959059 & MK958808 \\
\hline B. morwellensis & UoMAU14 & _- & Australia & - & MK958806 \\
\hline B. oblongielliptica & CBS 568.70 LT & Agaric & Japan & JN206278 & JN206533 \\
\hline B. oblongielliptica & CNUFC IL02 & Timomenus komarovi & South Korea & MZ171391 & MZ148715 \\
\hline B. oblongispora & CBS $569.70^{\text {NT }}$ & Soil & Japan & JN206251 & JN206407 \\
\hline B. oblongispora & CNUFC TKB11 & Skin of Bufo gargarizans & South Korea & MZ420786 & MZ148717 \\
\hline B. parvicylindrica & UoMAU $35^{\mathrm{T}}$ & Leaf litter & Australia & MK959109 & MK958727 \\
\hline B. parvicylindrica & UoMAU213 & - & Australia & - & MK958732 \\
\hline B. psychrophila & UoMAU55 ${ }^{\mathrm{T}}$ & Leaf litter & Australia & MK959093 & MK958749 \\
\hline B. psychrophila & UoMAU26 & - & Australia & - & MK958748 \\
\hline B. recurva & CBS 318.52 ET & Fragaria; diseased root & USA & JN206261 & JN206522 \\
\hline B. recurva & CBS 196.71 & - & n.a & JN206265 & JN206523 \\
\hline Backusella sp. & CBS 538.80 & Medicago sativa & Egypt & HM999964 & HM849692 \\
\hline B. tarrabulga & UoMAU5 $^{\mathrm{T}}$ & Leaf litter & Australia & MK959060 & MK958804 \\
\hline B. tarrabulga & UoMAU187 & - & Australia & - & MK958805 \\
\hline B. thermophila & $\mathrm{CNUFC} \mathrm{CSO2}^{\mathrm{T}}$ & Gryllus bimaculatus & South Korea & MZ171389 & MZ148713 \\
\hline B. thermophila & CNUFC CS03 & Gryllus bimaculatus & South Korea & MZ171390 & MZ148714 \\
\hline B. tuberculispora & CBS $562.66^{\mathrm{LT}}$ & - & India & JN206267 & JN206525 \\
\hline B. tuberculispora & CBS 570.70 & - & Japan & MH859852 & MH871631 \\
\hline B. variabilis & CBS $564.66^{\mathrm{LT}}$ & Excrements of human & India & JN206254 & JN206528 \\
\hline B. westeae & UoMAU4 ${ }^{\mathrm{T}}$ & $\begin{array}{l}\text { Contaminant during attempts to culture } \\
\text { Laccaria species from freshly collected } \\
\text { sporocarps }\end{array}$ & Australia & MK959061 & MK958796 \\
\hline Backusella 'group X' & UoMAU9 & - & Australia & MK959098 & MK958787 \\
\hline Backusella 'group $\mathrm{X}^{\prime}$ & UoMAU98 & - & Australia & MK959099 & MK958789 \\
\hline Mucor indicus & CBS 226.29 ET & - & Switzerland & HM999956 & HM849690 \\
\hline
\end{tabular}

Bold letters indicate strains and accession numbers determined in this study. CBS, Culture Collection of the Westerdijk Fungal Biodiversity Institute, The Netherlands; CNUFC: Chonnam National University Fungal Collection, Gwangju, South Korea; EML: Environmental Microbiology Laboratory (Fungarium, Chonnam National University, Gwangju, South Korea); UoMAU: National Herbarium of Victoria, Australia; URM: Micoteca Culture Collection, Universidade Federal de Pernambuco, Recife, Brazil. T, ET, LT, and ${ }^{\mathrm{NT}}$ : ex-type, ex-epitype, ex-lectotype and ex-neotype strains, respectively. 


\section{Results}

\subsection{Phylogenetic Analysis}

The phylogenetic relationship of the new Backusella species with accepted species was determined by analysis of concatenated sequence datasets of two loci (ITS and LSU). The combined ITS and LSU sequence dataset consisted of 49 taxa, and the aligned dataset was comprised of 1120 characters including gaps (ITS: $1-530$ and LSU: 531-1120). The BI and ML analyses of this dataset were based on the GTR + I + G model. The trees generated from Bayesian analyses showed the similar topologies (data not shown here). Therefore, we only present the tree obtained from ML analysis (Figure 2).

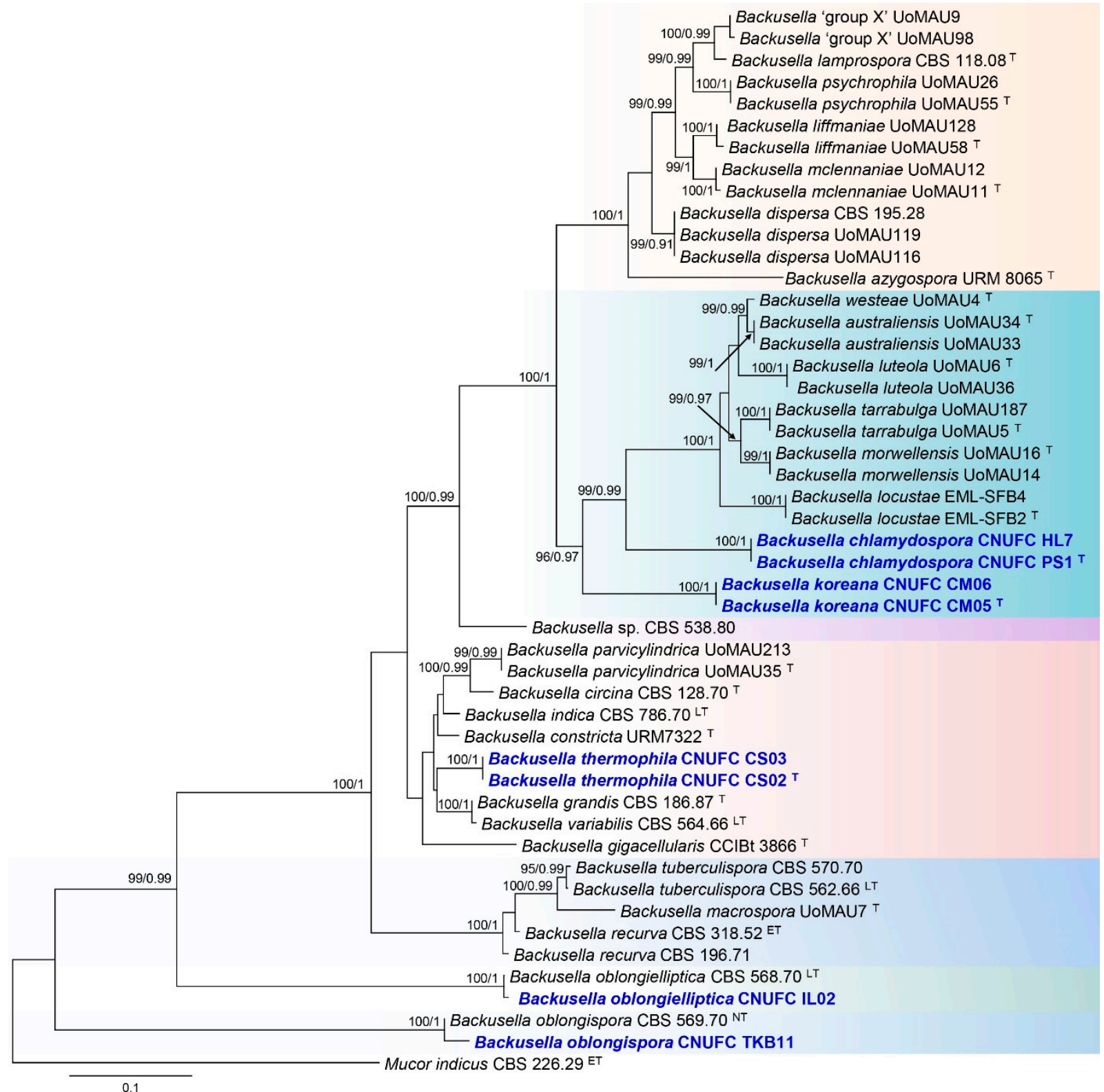

Figure 2. Phylogenetic tree constructed by maximum likelihood analysis of 49 sequences of the combined ITS and LSU. The numbers above branches represent maximum likelihood bootstrap percentages (left) and Bayesian posterior probabilities (right). Bootstrap values $\geq 70 \%$ and Bayesian posterior probabilities $\geq 0.90$ are shown. The bar indicates the number of substitutions per position. Mucor indicus CBS 226.29 was used as outgroup. Ex-type, ex-epitype, ex-lectotype, and ex-neotype strains are marked with ${ }^{\mathrm{T}}, \mathrm{ET}, \mathrm{LT}$, and ${ }^{\mathrm{NT}}$, respectively. Newly generated sequences are in bold blue. 
The two new species, CNUFC PS1 and CNUFC CM05, are close to B. locustae, B. morwellensis, B. tarrabulga, B. australiensis, B. westeae, and B. luteola, and they form a separate lineage based on multi-loci gene phylogeny. The new species CNUFC CSO2 is close to B. constricta, B. grandis, and B. variabilis, and it forms a separate lineage, while strains CNUFC IL02 and CNUFC TKB11 group together with reported species B. oblongielliptica and B. oblongispora, respectively, in a monophyletic clade (Figure 2).

\subsection{Taxonomy}

Our analysis revealed the presence of three new species and two new records in genus Backusella. These species are described below.

Backusella chlamydospora Hyang B. Lee \& T.T.T. Nguyen sp. nov. (Figure 3).

Index Fungorum: IF554922.

Etymology: Referring to the production of chlamydospores.

Type specimen: REPUBLIC OF KOREA, in a house garden located on a hill in Kunryangri $\left(36^{\circ} 44^{\prime} 00.2^{\prime \prime} \mathrm{N}, 126^{\circ} 78^{\prime} 18.0^{\prime \prime} \mathrm{E}\right)$, Cheongyang-eup, Cheongyang, Chungnam Province, from the head of a Porcellio scaber, 20 April 2020, H.B. Lee (holotype CNUFC HT2018; cultures ex-type CNUFC PS1).
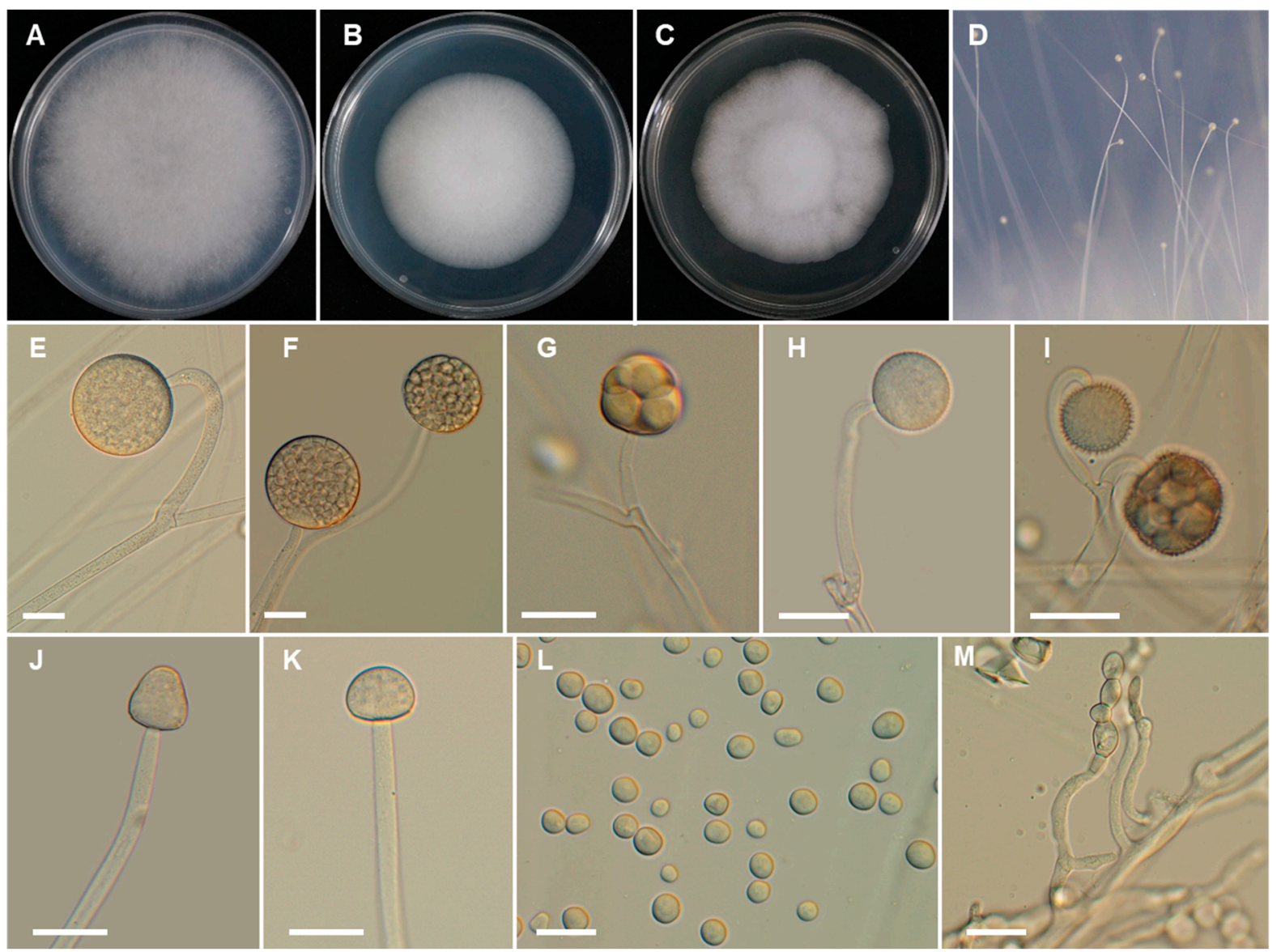

Figure 3. Morphology of Backusella chlamydospora. (A), Colony on SMA. (B), Colony on PDA. (C), Colony on MEA. (D), Sporangiophores forming sporangia. (E,F), Sporangia. (G), Multi-spored sporangiolum. (H), Uni-spored sporangiolum. (I), Uni- and multi-spored sporangiola borne on circinate branches. (J,K), Columellae of different shapes. (L), Sporangiospores. (M), Chlamydospores. Scale bars $=20 \mu \mathrm{m}$.

Description: Colonies develop rapidly on SMA, reaching a diameter of $62 \mathrm{~mm}$ after 4 days of incubation at $25^{\circ} \mathrm{C}$. Colonies white at first, become light gray with age; reverse light gray. Sporangiophores arising from the substrate mycelia curved when young and erect at maturity, with or without yellow granular content, frequently broaden upwards 
and then tapering slightly toward the sporangium, at first simple and later bearing pedicellate multispored or unispored sporangiola, $6.0-12.5 \mu \mathrm{m}$ diameter. Lateral circinate branches simple or rebranched: simple branches ending in a sporangium, multi-or unispored sporangiola, and complex branches ending in sporangiola, sometimes bearing a sterile sporangium. Sporangia globose to subglobose, multi-spored, with spinulose and deliquescent wall, yellowish but later turning brown, 35-80 $\times 35-75 \mu \mathrm{m}$. Columellae of sporangia variable in shape (subglobose, conical, ellipsoidal, cylindrical, hemi-spherical, or near pyriform; sometimes bell-shaped, long conical, or constricted at the middle portion), smooth, with or without yellowish granular contents, 18.5-35 × 15.5-30 $\mu \mathrm{m}$. Collar present. Multi-spored sporangiola contain (2-)3-18(-26) sporangiospores, globose to subglobose, (15-)17.5-35(-37) × (15-)17-33(-35) $\mu \mathrm{m}$, wall persistent, and spinulose. More abundant production of multi-spored sporangiola was observed after 8 days of culture. The columellae of sporangiola subglobose, or conical, up to $12.5 \mu \mathrm{m}$ diameter, smooth walled. Uni-spored sporangiola abundant near the substrate, globose, (10.5-)13.5-23(-30) $\mu \mathrm{m}$ diameter, wall persistent, and spinulose. The sporangiospores of sporangia and multi-spored sporangiola are similar: mostly subglobose or, less frequently, globose or irregular in shape, (6.5-)7.5$13.5(-15) \times(6-) 6.5-12.5(-13.5) \mu \mathrm{m}$. Sporangiospores from multi-spored sporangiola up to $20.5 \times 17.5 \mu \mathrm{m}$ in older cultures (15 days). Substrate mycelia highly branched, containing inflated regions ending in thin rhizoid-like filaments with green droplets. Chlamydospores produced after 4 days at the ends of vegetative hyphae, oidium-like, thick walled, terminal or in chains of 2 to 19 spores, globose to subglobose, 7.5-14.5 $\times 6.5-12 \mu \mathrm{m}$, or ellipsoidal or cylindrical to irregular, 9.5-23 × 7.5-13.5 $\mu \mathrm{m}$, thick-walled. Zygosporangia not observed. Culture characteristics: Colony diam, $72 \mathrm{~h}$, in mm: SMA $25^{\circ} \mathrm{C} 42$; SMA $20^{\circ} \mathrm{C} 33$; SMA $30{ }^{\circ} \mathrm{C} 30$; SMA $37^{\circ} \mathrm{C}$ no growth; MEA $25^{\circ} \mathrm{C} 39$; PDA $25^{\circ} \mathrm{C} 34$.

Additional material examined: REPUBLIC OF KOREA, in a house garden located on a hill in Kunryang-ri ( $\left.36^{\circ} 44^{\prime} 00.2^{\prime \prime} \mathrm{N}, 126^{\circ} 78^{\prime} 18.0^{\prime \prime} \mathrm{E}\right)$, Cheongyang-eup, Cheongyang, Chungnam Province, from the middle part of a Theuronema hilgendorfi hilgendorfi, 17 July 2020, H.B Lee (culture CNUFC HL7).

Backusella koreana Hyang B. Lee, J.S. Kim \& T.T.T. Nguyen, sp. nov. (Figure 4).

Index Fungorum: IF554923

Etymology. Referring to the country in which it was isolated.

Type specimen: REPUBLIC OF KOREA, in a house garden located on a hill of Kunryangri ( $\left.36^{\circ} 44^{\prime} 00.2^{\prime \prime} \mathrm{N}, 126^{\circ} 78^{\prime} 18.0^{\prime \prime} \mathrm{E}\right)$, Cheongyang-eup, Cheongyang, Chungnam Province, from the head of Scolopendra morsitans, 21 June 2020, H.B. Lee and J.S. Kim (holotype CNUFC HT2020; ex-type living culture, CNUFC CM05).

Description: Colonies on SMA developing rapidly, reaching $65 \mathrm{~mm}$ diameter after 4 days of incubation at $25^{\circ} \mathrm{C}$. Colonies white at first, becoming light gray when old; reverse light gray. Sporangiophores arising from substrate mycelia, curved when young and erect at maturity, with or without yellow granular content, frequently broader upwards and then tapering slightly toward the sporangium, at first simple, later bearing pedicellate multispored or unispored sporangiola, $6.5-15(-20) \mu \mathrm{m}$ wide. Lateral circinate branches simple or rebranched: simple branches end in sporangia, or multi or uni-spored sporangiola; branches ending in sporangiola sometimes bearing a sterile sporangium. Sporangia yellowish but later turning brown, globose to subglobose, multi-spored, (31-)40-70(-85) $\times 30-70(-80) \mu \mathrm{m}$, wall spinulose and deliquescent, yellowish but later turning brown. Columellae of sporangia globose to ellipsoidal, sometimes hemi-spherical, with or without yellowish granular contents, $20-30 \times 15-30 \mu \mathrm{m}$. Collar present. Multi-spored sporangiola production observed after 7 days of culture. Multi-spored sporangiola contain (2-)3-8(-10) sporangiospores, globose to subglobose, (13-)16-35(-40) $\times(12-) 15-32(-40) \mu \mathrm{m}$, wall spinulose and persistent. Columellae of sporangiola subglobose (up to $17 \mu \mathrm{m}$ long), or conical (up to $13 \mu \mathrm{m}$ long), smooth walled. Unispored sporangiola rare, globose, $15-30 \mu \mathrm{m}$ diameter, wall spinulose and persistent. Sporangiospores of sporangia and multi-spored sporangiola are similar, mostly subglobose or globose or irregular in shape, 10-18 $\times 10-17 \mu \mathrm{m}$. Substrate highly branched, containing inflated regions terminating in thin rhizoid-like 
filaments and green droplets. Yeast-like cells were abundant on SMA, globose to oval. Chlamydospores and zygospores not observed.
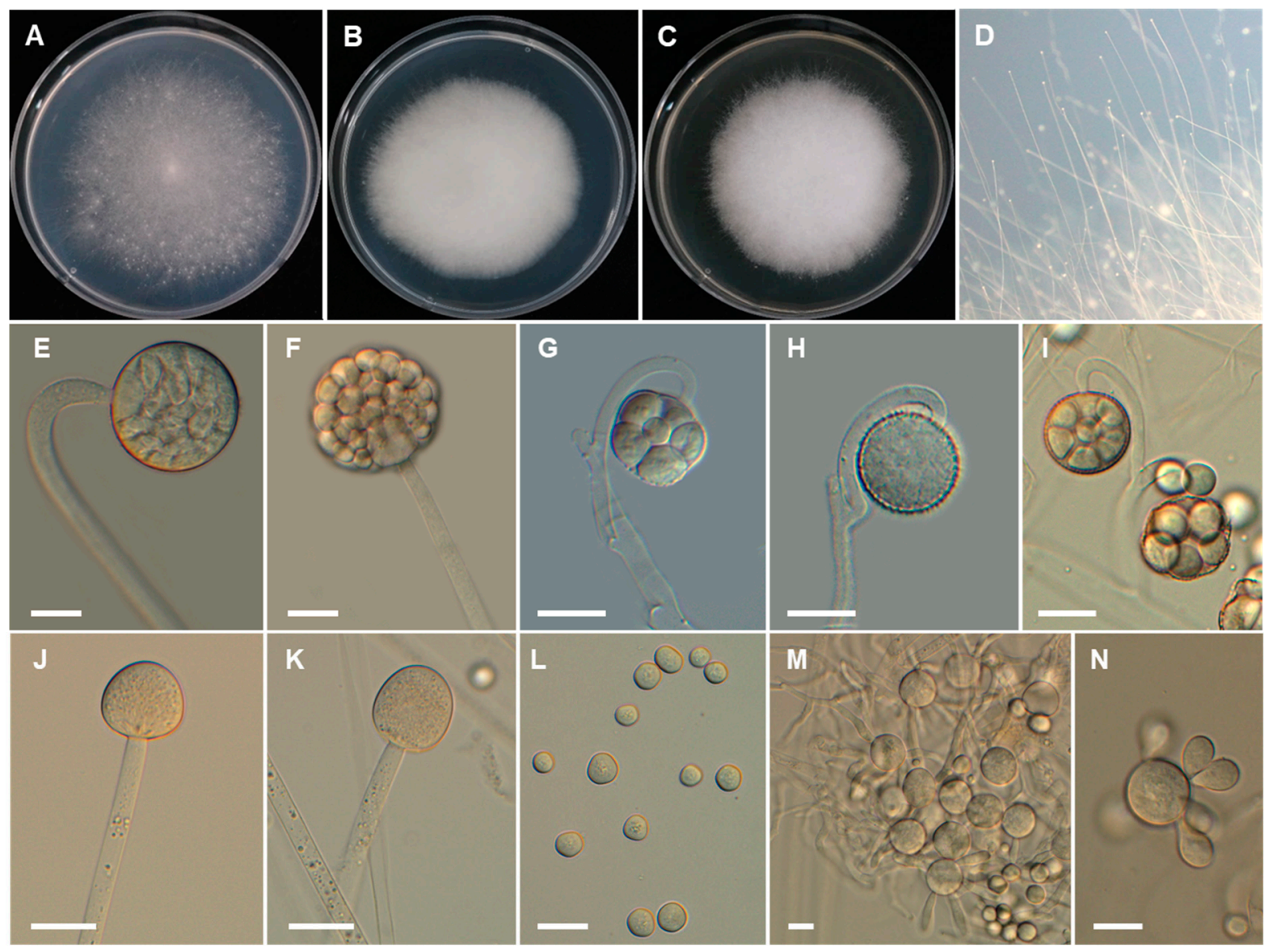

Figure 4. Morphology of Backusella koreana. (A), Colony on SMA. (B), Colony on PDA. (C), Colony on MEA. (D), Sporangiophores forming sporangia. (E,F), Sporangia. (G), Multi-spored sporangiolum. (H), Uni-spored sporangiolum. (I), Multi-spored sporangiola borne on circinate branches. (J,K), Columellae of different shapes. (L), Sporangiospores. (M,N), Yeast-like cells. Scale bars $=20 \mu \mathrm{m}$.

Culture characteristics: Colony diam, $72 \mathrm{~h}$, in mm: SMA $25^{\circ} \mathrm{C} 48$; SMA $20^{\circ} \mathrm{C} 33$; SMA $30{ }^{\circ} \mathrm{C}$ 30; SMA $10{ }^{\circ} \mathrm{C} 4$; SMA $37^{\circ} \mathrm{C}$ no growth; MEA $25^{\circ} \mathrm{C} 44$; PDA $25^{\circ} \mathrm{C} 46$.

Additional material examined: REPUBLIC OF KOREA, in a house garden located on a hill of Kunryang-ri ( $\left.36^{\circ} 44^{\prime} 00.2^{\prime \prime} \mathrm{N}, 126^{\circ} 78^{\prime} 18.0^{\prime \prime} \mathrm{E}\right)$, Cheongyang-eup, Cheongyang, Chungnam Province, from the head of a Scolopendra morsitans, 22 June 2020, H.B. Lee and J.S. Kim (culture CNUFC CM06).

Backusella thermophila Hyang B. Lee, A.L. Santiago, P.M. Kirk, K. Voigt \& T.T.T. Nguyen sp. nov. (Figure 5).

Index Fungorum: IF554924.

Etymology: Refers to the ability to grow and sporulate at high temperature $\left(>37^{\circ} \mathrm{C}\right)$.

Type specimen: REPUBLIC OF KOREA, in a house garden located on a hill of Kunryangri ( $\left.36^{\circ} 44^{\prime} 00.2^{\prime \prime} \mathrm{N}, 126^{\circ} 78^{\prime} 18.0^{\prime \prime} \mathrm{E}\right)$, Cheongyang-eup, Cheongyang, Chungnam Province, from the leg of Gryllus bimaculatus, on 27 July 2020, H.B. Lee (holotype, CNUFC HT2019; ex-type living culture, CNUFC CSO2). 

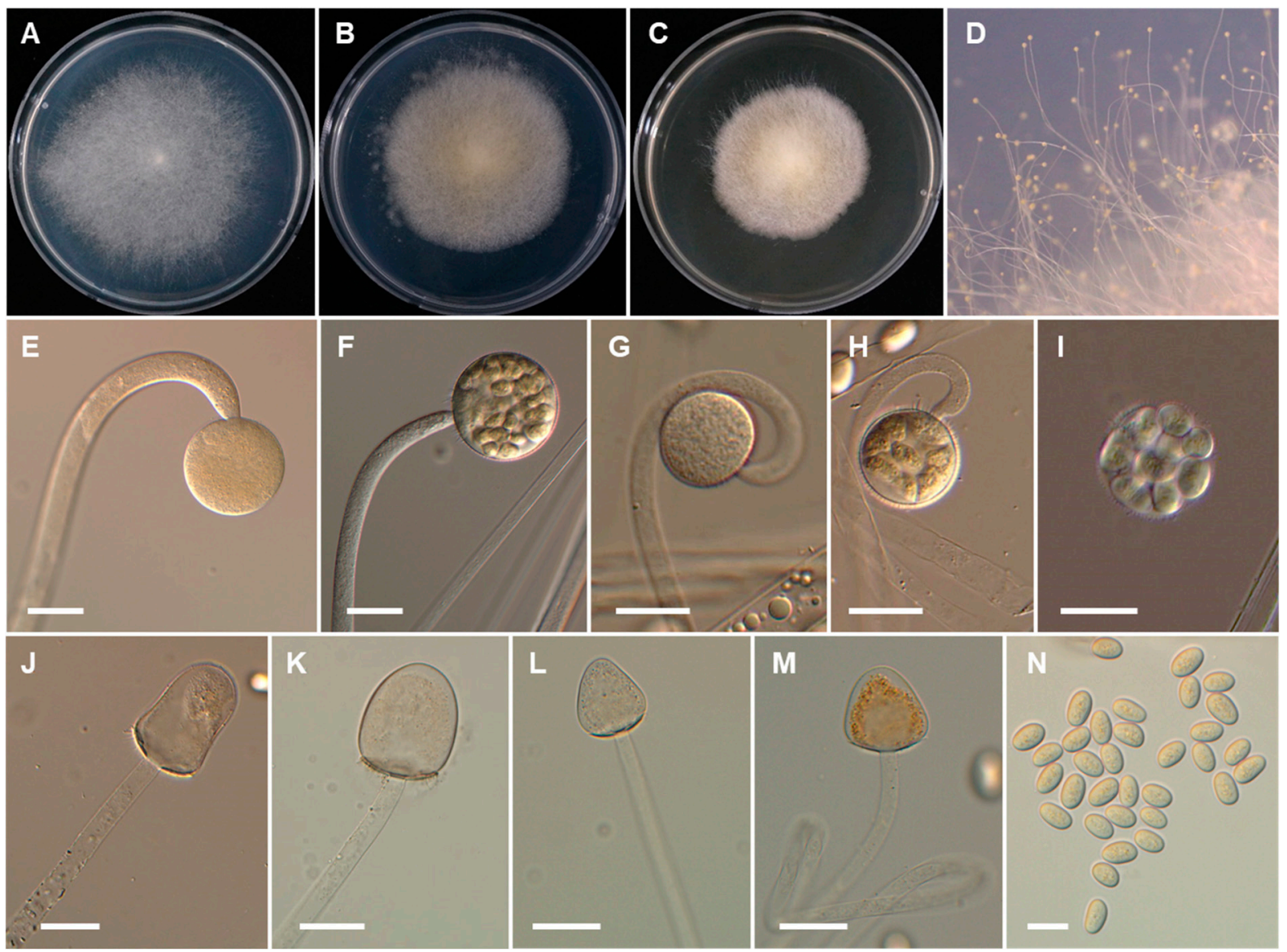

Figure 5. Morphology of Backusella thermophila. (A), Colony on SMA. (B), Colony on PDA. (C), Colony on MEA. (D), Sporangiophores forming sporangia. (E-H), Young and mature sporangia. (I), Multi-spored sporangiolum. (J-M), Columellae of various shapes. (N), Sporangiospores. Scale bars $=20 \mu \mathrm{m}$.

Description: Colonies on SMA developing rapidly, reaching $68 \mathrm{~mm}$ diameter after 4 days incubation at $25^{\circ} \mathrm{C}$. Colonies white at first, becoming light yellow when old; reverse light yellow. Sporangiophores arising from substrate mycelia curved when young and erect at maturity, 7.5-25 $\mu \mathrm{m}$; unbranched or, less frequently, with a short, recurved branch bearing a sterile sporangium, which quickly reaches the lid of the Petri dish. Sporangia yellow, deliquescent, globose to subglobose, (35-)40-95(-130) $\mu \mathrm{m}$ diameter, wall deliquescent, transparent, and spinulose, with spines 3.5-7.5 $\mu \mathrm{m}$ long. Columellae subglobose to oblong $(35-80 \times 30-70 \mu \mathrm{m})$, applanate to oval $(22-40 \times 20-30 \mu \mathrm{m})$, or conical or ellipsoidal to pyriform $(42-66 \times 33-48 \mu \mathrm{m})$, with or without brownish contents. Collars small. Multi-spored sporangiola production observed after 7 days; sporangiola contain (4-)8-18 sporangiospores, globose to subglobose, $20-40 \mu \mathrm{m}$ diameter, wall persistent and spinulose. Columellae of sporangiola subglobose or conical, 15-17 × 10-15 $\mu \mathrm{m}$, smooth walled. Unispored sporangiola rare, globose, up to $15 \mu \mathrm{m}$ diameter, spinulose. Sporangiospores of sporangia and multi-spored sporangiola mostly ellipsoidal, 14-20 × 10-13 $\mu \mathrm{m}$, yellowish or with yellow granules concentrated in the center. Substrate highly branched, containing inflated regions, and terminating in thin rhizoid-like filaments. Chlamydospores and zygospores not observed.

Culture characteristics: Colony diam, $72 \mathrm{~h}$, in mm: SMA $25^{\circ} \mathrm{C} 42$; SMA $20^{\circ} \mathrm{C} 33$; SMA $30{ }^{\circ} \mathrm{C} 45$; SMA $10^{\circ} \mathrm{C} 3$; SMA $37^{\circ} \mathrm{C} 38$; MEA $25^{\circ} \mathrm{C} 39$; PDA $25^{\circ} \mathrm{C} 43$.

Additional materials examined: REPUBLIC OF KOREA, in a house garden located on a hill in Kunryang-ri ( $\left.36^{\circ} 44^{\prime} 00.2^{\prime \prime} \mathrm{N}, 126^{\circ} 78^{\prime} 18.0^{\prime \prime} \mathrm{E}\right)$, Cheongyang-eup, Cheongyang, Chungnam Province, from the leg of Gryllus bimaculatus, 28 July 2020, H.B. Lee (culture CNUFC CS03). 
Backusella oblongielliptica (H. Nagan., Hirahara \& Seshita ex Pidopl. \& Milko) G. Walther \& de Hoog, Persoonia 30: 41 (2013) (Figure 6).
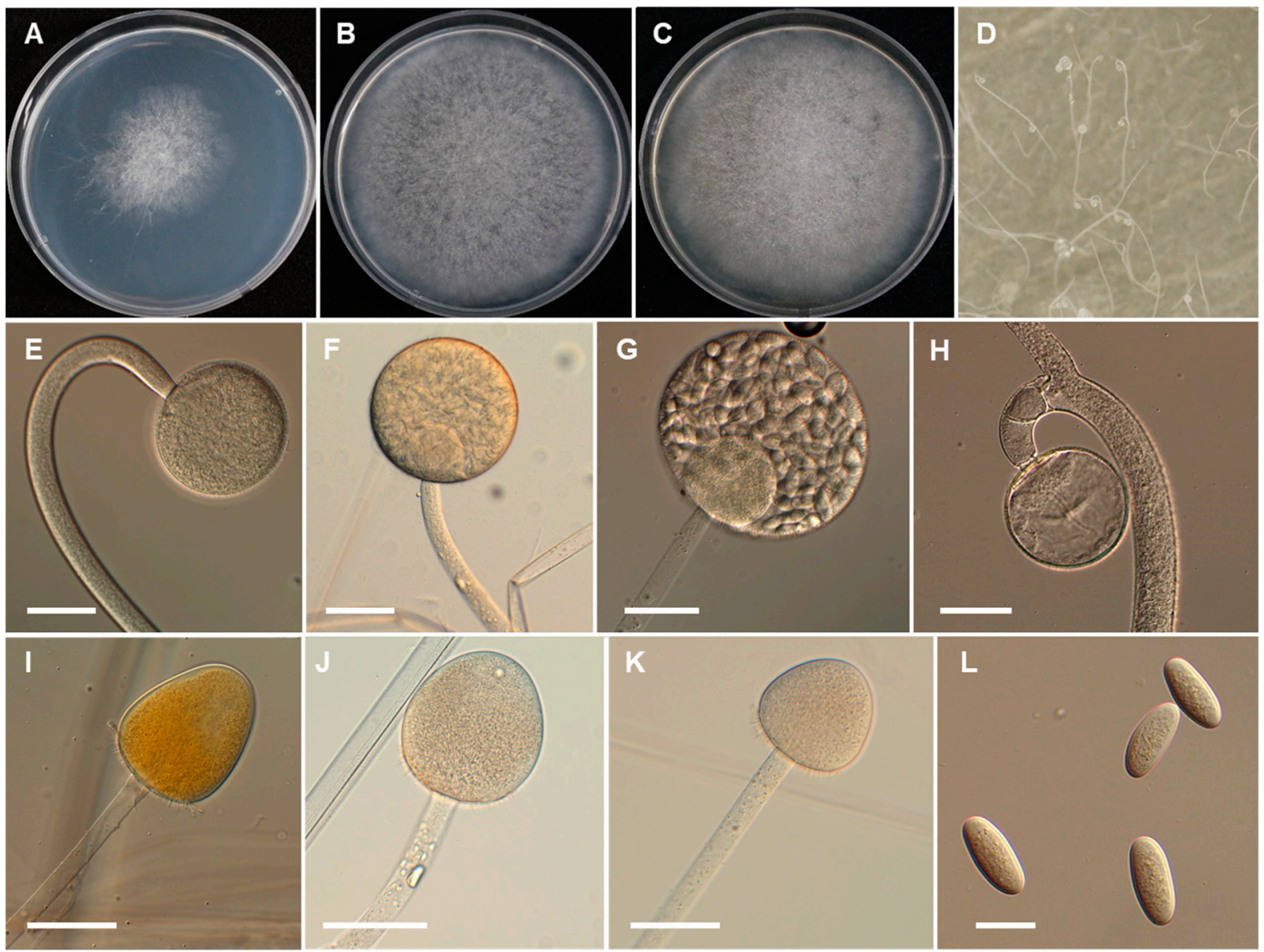

Figure 6. Morphology of Backusella oblongielliptica. (A), Colony on SMA. (B), Colony on PDA. (C), Colony on MEA. (D), Sporangium on circinate branches. (E-G), Young and mature sporangia. (H), Sterile sporangium. (I-K), Columellae of different shapes. (L), Sporangiospores. Scale bars: E-K $=50 \mu \mathrm{m}, \mathrm{L}=20 \mu \mathrm{m}$.

Basionym. Mucor oblongiellipticus H. Nagan., Hirahara \& Seshita ex Pidopl. \& Milko, Atlas Mukor. Grib. (Kiev): 81 (1971).

$\equiv$ Mucor oblongiellipticus H. Nagan., Hirahara \& Seshita, Essays Stud. Fac. Hiroshima Jogakuin College 18: 167 (1969), nom. inval., Art. 36.1.

Description: Colonies on SMA developing rapidly, reaching $72 \mathrm{~mm}$ diameter after 4 days incubation at $25{ }^{\circ} \mathrm{C}$. Colonies white; reverse white. Sporangiophores arising from substrate mycelia, curved when young and erect at maturity, 15-35 $\mu \mathrm{m}$ wide, unbranched or branched at the base. Sporangia yellow, exhibiting or not yellowish- or reddish-brown contents, globose to subglobose, 65-195(-215) × 60-180(-210) $\mu \mathrm{m}$, yellow, wall transparent and deliquescent. Columellae subglobose to ellipsoidal, (35-)40-90(-115) $\times(35-) 40-80(-$ 110) $\mu \mathrm{m}$. Collar present, some with needle-shaped spines. Sporangiospores oblong to ellipsoidal, (28-)30-40 × 12-15(-18) $\mu \mathrm{m}$, yellowish or with yellow granules concentrated in the center. Substrate mycelia highly branched. Sporangiola not formed. Chlamydospores, and zygospores not observed.

Culture characteristics: Colony diam, $72 \mathrm{~h}$, in mm: SMA $25^{\circ} \mathrm{C} 54$; SMA $20^{\circ} \mathrm{C} 59$; SMA $30{ }^{\circ} \mathrm{C} 46$; SMA $10^{\circ} \mathrm{C} 13$; SMA $37^{\circ} \mathrm{C}$ no growth; MEA $25^{\circ} \mathrm{C} 65$; PDA $25^{\circ} \mathrm{C} 70$.

Specimen examined: South Korea, in a house garden located on a hill of Kunryang-ri $\left(36^{\circ} 44^{\prime} 00.2^{\prime \prime} \mathrm{N}, 126^{\circ} 78^{\prime} 18.0^{\prime \prime} \mathrm{E}\right)$, Cheongyang-eup, Cheongyang, Chungnam Province, from the middle part of a Timomenus komarovi, 14 April 2020, J.S. Kim (culture CNUFC IL02). 
Backusella oblongispora (Naumov) G. Walther \& de Hoog, Persoonia 30: 41 (2013). (Figure 7).
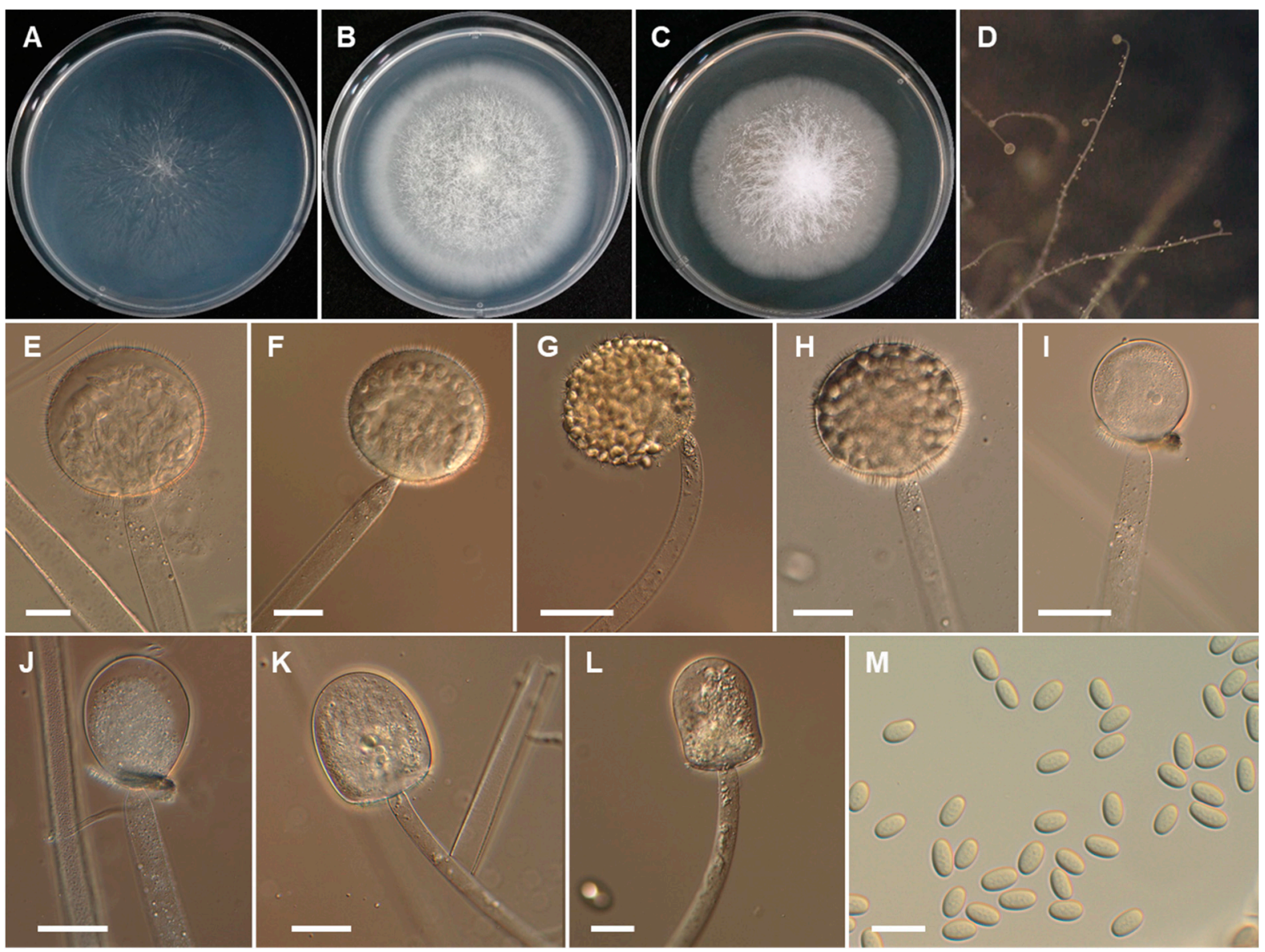

Figure 7. Morphology of Backusella oblongispora. (A), Colony on SMA. (B), Colony on PDA. (C), Colony on MEA. (D), Sporangium on circinate branches. (E-H), Young and mature sporangia. (I-L), Columellae of various shapes. (M), Sporangiospores. Scale bars: $\mathrm{E}-\mathrm{L}=50 \mu \mathrm{m}, \mathrm{M}=20 \mu \mathrm{m}$.

Basionym. Mucor oblongisporus Naumov, Mater. Mykol. Fitopatol. Rossii 1(4): 12 (1915).

Description: Colonies growing fast on SMA, reaching $58 \mathrm{~mm}$ diameter after 4 days incubation at $25^{\circ} \mathrm{C}$. Colonies white at first, becoming smoke gray when old; reverse white. Sporangiophores arising from substrate mycelium, curved when young, erect at maturity. Sporangiophores, $12-42 \mu \mathrm{m}$ wide, displaying a wider base and a slight constriction next to the sporangium, sporangiophores at first curved, unbranched, but later branched, sometimes bearing a sterile sporangium. Sporangia produced after $86 \mathrm{~h}$, yellowish, globose to subglobose, $(40-) 70-170(-265) \times(40-) 65-165(-260) \mu \mathrm{m}$, finely echinulate. Columellae exhibiting or not brownish contents, ellipsoidal to pyriform or oblong, 50-115(-160) $\times$ 40-80(-130) $\mu \mathrm{m}$. Collar present, some with needle-shaped spines. Sporangiospores ellipsoidal, $8.5-12 \times 14-18 \mu \mathrm{m}$, smooth-walled. Sporangiola not formed. Chlamydospores and zygospores not observed.

Culture characteristics: Colony diam, $72 \mathrm{~h}$, in mm: SMA $25^{\circ} \mathrm{C} 44$; SMA $20^{\circ} \mathrm{C} 38$; SMA $30{ }^{\circ} \mathrm{C} 36$; SMA $10^{\circ} \mathrm{C} 17$; SMA $37^{\circ} \mathrm{C}$ no growth; MEA $25^{\circ} \mathrm{C} 43$; PDA $25^{\circ} \mathrm{C} 53$.

Specimen examined: South Korea, in a house garden located on a hill in Kunryang-ri $\left(36^{\circ} 44^{\prime} 00.2^{\prime \prime} \mathrm{N}, 126^{\circ} 78^{\prime} 18.0^{\prime \prime} \mathrm{E}\right)$, Cheongyang-eup, Cheongyang, Chungnam Province, on skin of Bufo gargarizans, 11 June 2020, J.S. Kim (culture CNUFC TKB11). 


\section{Discussion}

Cheongyang, located in Chungnam Province, South Korea, covers a total area of 479.7 square kilometers, about $65.8 \%$ of which is forest, $7.3 \%$ field, and $14.7 \%$ paddy field. It is also known for the spicy gochu peppers that are produced in the region and for the fruit of the Chinese matrimony vine, or gugija, which make Cheongyang a favorable region for the growth of fungi. This area is more recognized as a hotspot for biodiversity and is known as the "Alps of Chungnam" and a place that needs to be preserved. In 2019, we found a new species of Mucor, M. cheongyangensis from the surface of Lycorma delicatula in this region [25]. Here, three new species to genus Backusella from the Cheongyang area are described and are compared with those of their most closely related species.

Our phylogenetic analyses showed that $B$. koreana and B. chlamydospora form a separate lineage, phylogenetically related to B. locustae, B. morwellensis, B. tarrabulga, B. australiensis, $B$. westeae, and B. luteola. However, the production of chlamydospores can be used to easily distinguish $B$. chlamydospora from these species. In addition, $B$. chlamydospora produces larger sporangia than B. luteola $(26-59 \times 23-55 \mu \mathrm{m})$, B. liffmaniae $(26-55 \times 26-54 \mu \mathrm{m})$, B. morwellensis $(23-72 \times 23-57 \mu \mathrm{m})$, and B. westeae $(26-64 \times 22-58 \mu \mathrm{m})$ [9]. As observed in B. chlamydospora, B. constricta, B. lamprospora, B. circina, and B. azygospora also produce both uni-spored and multi-spored sporangiola. Moreover, B. chlamydospora can grow at $35^{\circ} \mathrm{C}$, while $B$. azygospora is unable to grow at this temperature [5]. In addition, azygospores are quite common in the latter but not produced by the former. Like B. chlamydospora, B. circina and $B$. constricta also produce subglobose sporangiospores, but pyriform columellae have not been observed in either of these species. In addition, $B$. chlamydospora produces a higher number of spores per multi-spored sporangiola than B. constricta $(2-8)$ and B. circina $(2-14)[1,6]$. Backusella koreana is a sister taxon to B. chlamydospora. Both morphological and phylogenetic analyses indicate differences between these two new taxa. For example, $B$. chlamydospora produces a larger number of spores on multi-spored sporangiola than B. koreana. Furthermore, the sporangiospores of B. koreana are larger than those of B. chlamydospora. In addition, B. chlamydospora can be distinguished from B. koreana by production of chlamydospores. Finally, $B$. koreana produces abundant yeast-like cells on SMA medium. Backusella thermophila is phylogenetically related to B. constricta, B. grandis, and B. variabilis. Morphologically, the new species can be easily distinguished from $B$. constricta by the size and shape of sporangiospores that are subglobose to elliptical, some slightly irregular in shape, with 7.5-15 $\times 5.5-10 \mu \mathrm{m}$ in diameter in the later species [6]. In addition, B. constricta displayed limited growth at $37^{\circ} \mathrm{C}$, but $B$. thermophila was able to grow well even at $37^{\circ} \mathrm{C}$. Finally, B. constricta produces some constrict columellae, which are rarely observed in $B$. thermophila. In fact, $B$. thermophila produces columellae varied in shape (subglobose to oblong, applanate to oval, conical and ellipsoidal to pyriform), whereas $B$. grandis produces conical to cylindrical-ellipsoidal columellae $[4,26]$. Backusella grandis differs from $B$. thermophila by the production of bigger columella $(115-200 \times 100-180 \mu \mathrm{m})[4,26]$. Backusella thermophila and B. variabilis grow at $37^{\circ} \mathrm{C}$; however, $B$. thermophila differs from $B$. variabilis by having smaller sporangia and producing both multispored and uni-spored sporangiola [4,27]. Therefore, morphological analysis supported the results of molecular phylogenetic analysis, indicating that these new isolates are new species described here as B. chlamydospora, B. koreana, and B. thermophila.

Most species of Backusella are saprobic and commonly isolated from soil and leaf litter $[4,9]$. Some species have been found in excrement of humans, herbivores, or insects $[4,8,13]$. However, the genus Backusella has not been involved in human infections [28]. Interestingly, the new species (B. chlamydospora, B. koreana, and B. thermophila), and two newly recorded species (B. oblongielliptica and B. oblongispora) of Backusella were first discovered from invertebrate and toad samples. The presence of Backsuella species in different substrates reflects their ecological importance in ecosystems. Further studies on the fungal diversity of the niches are needed to understand the relationships between these organisms in ecosystems. 
The identification of these novel species expands the range of potential habitats of the members of this genus. This suggests that unknown micro-fungi, especially those belonging to the genus Backusella, have not yet been described and that invertebrate samples may be a rich source of novel species of fungi.

Key to Backusella species in Korea

1. Chlamydospores present .................... chlamydospora

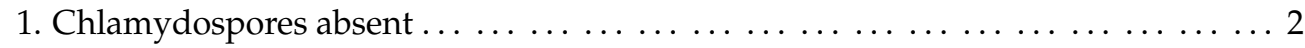

2. Yeast-like cells present $\ldots \ldots \ldots \ldots \ldots \ldots \ldots \ldots \ldots \ldots \ldots \ldots \ldots \ldots \ldots \ldots$

2. Yeast-like cells not observed $\ldots \ldots \ldots \ldots \ldots \ldots \ldots \ldots \ldots \ldots \ldots \ldots$

3. Sporangia commonly bigger than $150 \mu \mathrm{m}$ diam., sporangiola not formed . . . . . 5

3. Sporangia up to $130 \mu \mathrm{m}$ diam., sporangiola formed . . . . . . . . . . . . . 4

4. Unispored sporangiola abundant . . . . . . . . . . . . . . B. circina

4. Unispored sporangiola rarely present, or not observed $\ldots \ldots \ldots \ldots \ldots \ldots$

5. Columellae subglobose to ellipsoidal; sporangiospores oblong to ellipsoidal, (28-) $30-40 \times 12-15(-18) \mu \mathrm{m} \ldots \ldots \ldots \ldots \ldots \ldots \ldots \ldots \ldots \ldots \ldots \ldots \ldots$. oblongielliptica

5. Columellae ellipsoidal to pyriform; sporangiospores ellipsoidal, $8.5-12 \times 14-18 \mu \mathrm{m}$ $\ldots \ldots \ldots \ldots \ldots \ldots \ldots \ldots \ldots \ldots \ldots \ldots \ldots \ldots \ldots \ldots \ldots \ldots \ldots \ldots$. oblongispora

6. Sporangiospores globose to subglobose; no growth at $37^{\circ} \mathrm{C} \ldots \ldots$. . . B. locustae

6. Sporangiospores ellipsoidal; good growth and sporulation at $37^{\circ} \mathrm{C} \ldots$ B. thermophila

Author Contributions: Conceptualization, H.B.L. and T.T.T.N.; methodology, T.T.T.N. and H.B.L.; software, T.T.T.N.; validation, H.B.L.; formal analysis, T.T.T.N. and H.B.L.; investigation, T.T.T.N. and H.B.L.; resources, H.B.L.; writing-original draft, T.T.T.N. and H.B.L.; writing-review and editing, T.T.T.N., K.V., A.L.C.M.d.A.S., P.M.K., and H.B.L.; supervision, H.B.L.; funding acquisition, H.B.L.; project administration, H.B.L. All authors have read and agreed to the published version of the manuscript.

Funding: This study was financially supported by Chonnam National University [Grant number: 2017-2827]. This work was partly supported by the Graduate Program for the Undiscovered Taxa of Korea, and the Project on Survey and Discovery of Indigenous Fungal Species of Korea funded by National Institute of Biological Resources of the Ministry of Environment (MOE), Korea.

Institutional Review Board Statement: Not applicable.

Informed Consent Statement: Not applicable.

Data Availability Statement: All sequences generated in this study were submitted to GenBank.

Acknowledgments: The authors sincerely thank Lee's mother, Jeong Suk Kim, for kindly providing insect and toad samples.

Conflicts of Interest: The authors declare no conflict of interest.

\section{References}

1. Ellis, J.J.; Hesseltine, C.W. Two new members of the Mucorales. Mycologia 1969, 61, 863-872. [CrossRef]

2. Pidoplichko, N.M.; Mil'ko, A.A. Atlas of Mucoralean Fungi; Academy of Sciences of the Ukrainian SSR: Kiev, Ukrainian SSR, 1971; p. 188. (In Russian)

3. Benny, G.L.; Benjamin, R.K. Observations on Thamnidiaceae (Mucorales). New taxa, new combinations, and notes on selected species. Aliso 1975, 8, 301-351. [CrossRef]

4. Walther, G.; Pawłowska, J.; Alastruey-Izquierdo, A.; Wrzosek, M.; Rodriguez-Tudela, J.L.; Dolatabadi, S.; Chakrabarti, A.; de Hoog, G.S. DNA barcoding in Mucorales: An inventory of biodiversity. Persoonia 2013, 30, 11-47. [CrossRef]

5. Crous, P.; Carnegie, A.J.; Wingfield, M.J.; Sharma, R.; Mughini, G.; Noordeloos, M.E.; Santini, A.; Shouche, Y.S.; Bezerra, J.D.P.; Dima, B.; et al. Fungal Planet description sheets: 868-950. Persoonia 2019, 42, 291-473. [CrossRef] [PubMed]

6. Lima, D.X.; Voigt, K.; de Souza, C.A.; de Oliveira, R.J.; Souza-Motta, C.M.; Santiago, A.L.C.M.d.A. Backusella constricta sp. nov. (Mucorales, ex Zygomycota) from the Brazilian Atlantic Rainforest, including a key to species of Backusella. Phytotaxa 2016, 289, 59-68. [CrossRef]

7. de Souza, J.I.; Marano, A.V.; Pires-Zottarelli, C.L.A.; Chambergo, F.S.; Harakava, R. A new species of Backusella (Mucorales) from a Cerrado reserve in Southeast Brazil. Mycol. Prog. 2014, 13, 975-980. [CrossRef] 
8. Wanasinghe, D.N.; Phukhamsakda, C.; Hyde, K.D.; Jeewon, R.; Lee, H.B.; Jones, E.B.G.; Tibpromma, S.; Tennakoon, D.S.; Dissanayake, A.J.; Jayasiri, S.C.; et al. Fungal diversity notes 709-839: Taxonomic and phylogenetic contributions to fungal taxa with an emphasis on fungi on Rosaceae. Fungal Divers. 2018, 89, 1-236. [CrossRef]

9. Urquhart, A.S.; Douch, J.K.; Heafield, T.A.; Buddie, A.G.; Idnurm, A. Diversity of Backusella (Mucoromycotina) in south-eastern Australia revealed through polyphasic taxonomy. Persoonia 2021, 46, 1-25. [CrossRef]

10. Kirk, P.M. Nomenclatural novelties. Index Fungorum. 2012, 11, 1.

11. Nguyen, T.T.T.; Lee, H.B. Isolation and characterization of three Zygomycetous fungi in Korea: Backusella circina, Circinella muscae, and Mucor ramosissimus. Mycobiology 2018, 46, 317-327. [CrossRef] [PubMed]

12. Benny, G.L. Current systematics of Zygomycota with a brief review of their biology. In Systematics and Evolution of Fungi; Misra, J.K., Tewari, J.P., Deshmukh, S.K., Eds.; Science: Enfield, UK, 2012; pp. 55-105.

13. Santiago, A.L.C.M.d.A.; Trufem, S.F.B.; Malosso, E.; Santos, P.J.P.; Cavalcanti, M.A.de.Q. Zygomycetes from herbivore dung in the ecological reserve of Dois Irmãos, Northeast Brazil. Braz. J. Microbiol. 2011, 42, 89-95. [CrossRef]

14. Choi, Y.W.; Hyde, K.D.; Ho, W.H. Single spore isolation of fungi. Fungal Divers. 1999, 3, $29-38$.

15. de Hoog, G.S.; Gerrits van den Ende, A.H.G. Molecular diagnostics of clinical strains of filamentous Basidiomycetes. Mycoses 1998, 41, 183-189. [CrossRef]

16. White, T.J.; Bruns, T.; Lee, S.; Taylor, J. Amplification and direct sequencing of fungal ribosomal RNA genes for phylogenetics. In PCR Protocols: A Guide to Methods and Applications; Innis, M.A., Gelfand, D.H., Sninsky, J.J., White, T.J., Eds.; Academic Press: San Diego, CA, USA, 1990; pp. 315-322.

17. Bunyard, B.A.; Nicholson, M.S.; Royse, D.J. A systematic assessment of Morchella using RFLP analysis of the 28S ribosomal RNA gene. Mycologia 1994, 86, 762-772. [CrossRef]

18. Vilgalys, R.; Hester, M. Rapid genetic identification and mapping of enzymatically amplified ribosomal DNA from several Cryptococcus species. J. Bacteriol. 1990, 172, 4238-4246. [CrossRef]

19. Capella-Gutiérrez, S.; Silla-Martínez, J.M.; Gabaldón, T. trimAl: A tool for automated alignment trimming in large-scale phylogenetic analyses. Bioinformatics 2009, 25, 1972-1973. [CrossRef]

20. Glez-Peña, D.; Gómez-Blanco, D.; Reboiro-Jato, M.; Fdez-Riverola, F; Posada, D. ALTER: Program-oriented format conversion of DNA and protein alignments. Nucleic Acids Res. 2010, 38, 14-18. [CrossRef]

21. Guindon, S.; Dufayard, J.F.; Lefort, V.; Anisimova, M.; Hordijk, W.; Gascuel, O. New algorithms and methods to estimate maximum-likelihood phylogenies: Assessing the performance of PhyML 3.0. Syst. Biol. 2010, 59, 307-321. [CrossRef]

22. Ronquist, F.; Teslenko, M.; van der Mark, P.; Ayres, D.L.; Darling, A.; Höhna, S.; Larget, B.; Liu, L.; Suchard, M.A.; Huelsenbeck, J.P. MrBayes 3.2: Efficient Bayesian phylogenetic inference and model choice across a large model space. Syst. Biol. 2012, 61, 539-542. [CrossRef] [PubMed]

23. Guindon, S.; Gascuel, O. A simple, fast, and accurate algorithm to estimate large phylogenies by maximum likelihood. Syst. Biol. 2003, 52, 696-704. [CrossRef] [PubMed]

24. Darriba, D.; Taboada, G.L.; Doallo, R.; Posada, D. jModelTest 2: More models, new heuristics and parallel computing. Nat. Methods. 2012, 9, 772. [CrossRef]

25. Nguyen, T.T.T.; Lee, H.B. Mucor cheongyangensis, a new species isolated from the surface of Lycorma delicatula in Korea. Phytotaxa 2020, 446, 33-42. [CrossRef]

26. Schipper, M.A.A.; Samson, R.A. Miscellaneous notes on Mucoraceae. Mycotaxon 1994, 50, 475-491.

27. Sarbhoy, A.K. Mucor variabilis sp. nov. from India. Trans. Brit. Mycol. Soc. 1965, 48, 559-560. [CrossRef]

28. Walther, G.; Wagner, L.; Kurzai, O. Updates on the taxonomy of Mucorales with an emphasis on clinically important taxa. J. Fungi 2019, 5, 106. [CrossRef] 